\title{
Trust towards zakat institutions among Muslims business owners
}

\author{
Muhammad Ridhwan AB. Aziz, Nur Aqilah Hazirah Mohd Anim \\ Faculty of Economics and Muamalat, Universiti Sains Islam Malaysia, Bandar Baru Nilai, \\ Negeri Sembilan, Malaysia \\ ${ }^{*}$ Corresponding author: ridhwan.aziz@usim.edu.my
}

\section{Keywords: \\ Zakat, trust, board capital composition, disclosure practices, stakeholder management}

\section{Article History}

Received: 21 October 2019

Accepted: 30 December 2019

Published: 20 January 2020

DOI:

10.20885/JEKI.vol6.iss1.art1

JEL:

G28, H55, I13, M11, P35, Z12

\begin{abstract}
Society nowadays are aware on the immediate need of financial assistance to the poor and triggered the problem of direct payment of zakat to the eligible party. However, this practice may be ineffective as it will create bias on zakat distribution and zakat payment through zakat institution is encourage. In order to achieve this practice, zakat payers' trust in zakat institutions must be cultivated and maintained. This study examined the antecedents of zakat payers' trust among Muslim business owners based on three factors were which are board capital composition, disclosure practice and stakeholder management. This research employed quantitative research whereby 97 questionnaires among business owners were collected and analysed using multiple regression analysis. The finding revealed that disclosure practice and stakeholder management have a significant relationship with trust. This indicates that zakat institutions are urged to be transparent in their management especially in terms of financial disclosure to their stakeholder.
\end{abstract}

\section{Cite This:}

Aziz, M.R. A.B \& Anim, N.A.H M. (2020). Trust towards zakat institutions among muslims business owners. Jurnal Ekonomi dan Keuangan Islam, 6(1), 1-9. DOI: 10.20885/JEKI.vol6.iss1.art1

\section{Introduction}

The Islamic social finance constitutes of zakat, waqf, sadaqah and qard hasn (Abojeib \& Habib, 2019). In Malaysia, most of the zakat institutions are operated under the State Religious Islamic Council (SRIC) to manage all the affairs related to religion including the collection and distribution of zakat. However, in several states, administration of zakat has been privatized and special zakat institutions were established. The privatization of zakat institutions has improved the zakat collection and distribution (Muhammad, et al., 2015; Wahid, et al., 2006). The general impact of the privatization of zakat administration causes no voluntary zakat institutions in Malaysia. The only option for public to perform their obligation to pay zakat is through the established zakat institutions. Therefore, if the public do not trust zakat institutions, they will find another alternative channel to perform this obligation. The only alternative mean available for them is to pay zakat directly to the beneficiaries.

According to Wahib, et al. (2006), 10.5\% of respondents in their studies interested to pay zakat directly to the beneficiaries. In order to curb this problem, Muslim jurists issued a fatwa in June 2016, stated that zakat payment via alternative channel is not valid and against the fatwa as it will create bias in identifying the beneficiaries (Ghazali, et al., 2016).

Issue of trust deficit among Muslim society towards zakat institutions is alarming. Every year, there are many complaints against the zakat institutions made by public which have been reported in the media that expressed their discontent particularly in zakat distribution. According 
to Patmawati (2008), zakat plays a critical role in achieving justice and socio-economic status of Muslims, particularly the poor from being isolated from the general population. Thus, this issue will threaten the Muslim community itself since the effectiveness of zakat institutions is depending on the level of zakat collection which provided from the same community.

Few reasons were identified for this issue to arise. The main reason is on the management of zakat institutions in distributing zakat inefficiently compared to the collected amount of zakat. Besides, the image and reputation of zakat institutions have been tarnished due to bribery and deviation committed by zakat officer. On zakat payers' perspective, the procedure of zakat application is inconvenienced for the experiences of rejection for the zakat application. These issues need to be address carefully and fast as it involves trust and goodwill of zakat institutions.

At present, the total collection of business zakat is relatively low compare to zakat on income. It is believed that some individuals pay their zakat directly to the beneficiaries (Wahib, et al., 2009). It can be implied that the trust of zakat payers on zakat institutions is less to fulfill the objective of helping the poor and destitute. Although the fatwa had forbidden any zakat payment made directly to the beneficiaries, it was failed to curb the practice of direct distribution as zakat payers have been dissatisfied with the inefficiency of zakat distribution by the institutions (Wahib, et al., 2009).

Hence, trust is being the major problem faced by zakat institutions in Malaysia to collect zakat from business owners. This research proposed three factors which are board capital composition, disclosure practice and stakeholder management to influence trust towards zakat institutions. Although past researchers have address the issue of trust and zakat (Mustafa, et al., 2013; Zainal, et al., 2016) however, these researchers focus on individual zakat which implies that business zakat is unexplored realm.

Trust is always a key element in a contract that involves two or more parties. In zakat management, trust of zakat payers should be the top priority of zakat institutions. Being a trusted body, it is important for zakat institutions as it may improve zakat collection and this consequently provides dynamism in the fiscal management of a country (Hasan, 1987). In addition, the efficient zakat management of zakat institutions is one of the prerequisites that may gain zakat payers' trust.

A study by Hasan (1987) affirmed that there is a need for ensuring efficient zakat distribution as a means to compromise the trust relationship between the zakat institutions and zakat payers. In compromising the zakat payers' trust towards zakat institutions, the study found few things should be followed by zakat institutions; the collection of zakat should disburse immediately to the zakat recipients as it is their rights to have it and they are obviously in need of the zakat assistance, zakat collection in a particular area should preferably be disbursed to the zakat recipient in that particular area of collection, ensuring a good bond of brotherhood and healthy atmosphere for strong cooperation in that particular area, zakat fund should be disbursed to maximize the benefits of the zakat recipients economically and spiritually so that they will someday become a zakat payer and do not remain as zakat recipients, being the most important fiscal instrument for Muslims, zakat expenditure must aim to achieve the objectives of economic equity, growth and stability (Hasan, 1987). With regard to the contribution of zakat to the economic development of Muslims, efficient zakat management helps in developing a positive perception of zakat payers towards zakat institutions. Such positive perception suggests the important role and competence of the zakat institutions which this may probably strengthen the trust bonding among the zakat institution's stakeholders.

Moreover, various researches have pointed out the significant role of trust in defining both the credibility and legitimacy of charity organizations (Sergeant and Lee, 2004). Zakat payers' decision is very important in contribution of zakat funds as individual payers constitute the largest zakat source. 
Previous studies related to trust among zakat payers mostly concentrated on zakat fitrah (Zakaria, 2009; Obieoya, et al., 2011; Salleh \& Ahmad, 2011). Nevertheless, a few research have been conducted specifically on business zakat (Ghazali, et al., 2016; Wahab \& Borhan, 2014). However, research on business zakat are lack of statistical evidence since both of the studies attempted to develop the conceptual framework.

Many of the past researchers agreed that distribution of zakat fund is the most important factors in gaining zakat payers trust. Salleh \& Ahmad (2011) conducted a study on public confidence level of zakat distribution. The study derived five factors which are human factor, non-human factor, collection factor, distribution factor and corporate image of the zakat institutions. The result appears that collection and distribution factor are the important factor that influence confident level of public for zakat payment. Research finding by Obieoya, et al. (2011) also points towards zakat distribution. This study was conducted in Nigeria to investigate the antecedent of zakat payer trust particularly on zakat fitrah (tithe). The researchers construct an empirical model comprises of four factors which are perception on board capital of a particular zakat institutions, perception on disclosure practice, perception on stakeholder management and perception on nature of zakat institutions in term of distribution's efficiency and effectiveness. The finding highlight three of the factors are found to be the important determinants except perception on board capital composition.

In term of trust among business owners, Wahab \& Borhan (2014) conducted a theoretical review of determinants factors for zakat payment by business entities in Malaysia. This study based on Theory of Planned Behaviour (TPB), compliance model theory and economic theory and critically revised 24 factors from prior literatures. The finding is consistent with the study by the previous researchers which include the effectiveness of distribution managed by zakat institutions is one of the significant determinant by business owners in Malaysia. In addition, according to Ghazali et al. (2016) who proposes a theoretical framework also listed distribution is one of the factor contributing to influence zakat payment by business owners. However, these studies are conceptual in nature, therefore, no statistical analyses and empirical evidence are provided.

Other factors related to trust is disclosure practice or transparency. Mustafa, et al. (2013) on their research based on dependency and legitimacy theory and donor trust literatures found that perception on disclosure practice contribute to gain public trust towards zakat institutions. Similarly, Wahab \& Borhan (2014) found that organizational factors which comprise transparency is a catalyst to other two factors which are governmental factors and internal factors. This study suggested that zakat institutions can be a push factor to the government to improvise the policy especially on tax exemption. This supported by Zakaria (2009) who did a research specifically on management of zakat institutions in Indonesia and the relationship with the public trust. The research found that in order to increase public trust, it is expected that zakat institutions should maximize the quality of service that covers the principles of fairness, transparency and responsibilities.

Composition of board capital is significant as contributing factors of trust among zakat payers. Mustafa, et al. (2013) showed that right combination of members in zakat institutions board will enhance the trust. On the same factor but in different perspectives, Wahab \& Borhan (2014) found that board directors' composition of a business entities is important to create trust and increase their zakat payment.

Hillman \& Dalziel (2003) opined that board members are often influential factors on firm behaviour due to their supervisory roles. This is particularly true in their identification and setting of the company's goals and objectives and the ability to meet them. Supporting the above arguments, given the diversity of individuals, board members introduce a diverse range of skills and values. These diverse skills and values are likely to influence the organization's values and priorities. In light of this, board capital composition is expected to be a critical factor of stakeholder management practices. Social and financial status of the board members and their 
ability to provide resources have implication for zakat institutions. Prestigious and committed boards should be able to attract more zakat payment to the zakat institutions. Based on the arguments by previous literatures, the hypothesis was framed as follows:

H1: Perception of the board capital composition of zakat institutions will have a positive influence on trust towards zakat institutions among zakat payers.

Baharum (1989) established that the lack of information disseminated to the public is the reason for limited public confidence towards zakat administration, this may lead to the payment of zakat directly to the recipients. In that case, zakat administrators should be more transparent to the zakat payers by providing information about the collection and distribution of zakat. Such actions indicate that zakat administrators are accountable and transparent in managing the zakat fund and are expected to create a strong trust among the zakat payers. Therefore, the second hypothesis is as follows;

H2: Perception of the quality of the disclosure practices of zakat institutions will have a positive influence on trust towards zakat institutions among zakat payers.

Mustafa et al. (2013) suggested that zakat payers would trust zakat institutions if the institutions treat zakat recipient and other stakeholders in a favorable manner. This is an indicator of sound stakeholder's management. Berman et. al. (1999) refers to the management of stakeholder's management as how the management uses the resource economically for intended beneficiaries. Therefore, the third hypothesis is developed as follows;

H3: Perception of the quality of stakeholder management practices of zakat institutions will have a positive influence on trust towards zakat institutions among zakat payers.

\section{Research Method}

This study employed quantitative research and conducted in Negeri Sembilan, Malaysia. The decision to conduct this research in that particular area is due to the inconsistent business zakat collection each year in this state. The sampling frame of this study refers to business owners who are categorized under Small Medium Enterprise (SMEs) and involved in food and beverages manufacturing. The reason is, according to Economic Census in 2011, this sector has the most contribution in gross output for Malaysia with RM69.5 billion. This indicates that food and beverages sector has large sales amount compared to other sectors and has the huge potential for zakat collection. In determining the population, there are 127 food and beverages companies in Negeri Sembilan registered under SME Corporation of Malaysia. The study used convenient sampling method and by referring to table by Krejcie \& Morgan (1970), the sample for this study are 97 individuals who owns the business.

A set of questionnaire used in this study were employed from the study by Mustafa et al. (2013). The questionnaire contains of nine items and measured by 5 points Likert scale indicates that $1=$ strongly disagree, $2=$ disagree, $3=$ neither agree nor disagree, $4=$ agree and $5=$ strongly agree. The Likert-type Scale is used because of its suitability for self-administered surveys, irrespective of whether the data are collected online or offline. The questionnaire of this study provided as below.

Perception of Board Capital Composition

1. It will be very helpful to have a Shari'ah scholar on the board of zakat institutions.

2. At least, a representative of zakat payers may need to be on the board of zakat institution.

3. Zakat institutions can be relied on to have a board that has reputable members.

Perception of Disclosure Practices

4. Zakat institutions should disclose full financial information in the audited report.

5. Zakat institutions should disclose their achievements in audited report.

Perception of Stakeholder Management 
6. Zakat institutions may systematically assess the satisfaction of zakat payers on a regular basis.

7. Zakat institution can be relied on to act in line with Shari'ah in all its activities.

Trust Toward zakat Institutions

8. Zakat institution can be relied on to disclose information on zakat funds honestly.

9. Zakat institution can be relied on not to allocate zakat funds for other services.

Overall, the majority of the respondents were female (52.7\%); the average age was in the range of 21 - 30 years old (40.5\%); 41.9\% are Bachelor Degree holder, and most of the respondents have been involved in business activities less than five years (59.5\%).

Table 1. Descriptive Statistic

\begin{tabular}{lc}
\hline Gender & \\
\hline Male & $47.3 \%$ \\
Female & $52.7 \%$ \\
\hline Age & \\
\hline Less than 20 years & $12.2 \%$ \\
$21-30$ years & $40.5 \%$ \\
31-40 years & $14.9 \%$ \\
41-50 years & $14.8 \%$ \\
More than 50 years & $17.6 \%$ \\
\hline Education & \\
\hline Secondary School and below & $18.9 \%$ \\
Diploma/Certificate & $35.1 \%$ \\
Bachelor & $41.9 \%$ \\
Master & $4.1 \%$ \\
\hline Number of Years Doing Business & \\
\hline 1-5 years & $59.5 \%$ \\
6-10 years & $21.6 \%$ \\
11-15 years & $8.1 \%$ \\
16-20 years & $1.4 \%$ \\
More than 20 years & $9.5 \%$ \\
\hline
\end{tabular}

After look into the descriptive statistic, reliability test then was conducted to check the internal consistency between each item (Sekaran \& Bougie, 2009). Table 2 shows the result from the reliability test. As a rule of thumb, a Cronbach's alpha should be higher than 0.7 (Pallant, 2005). Since the Cronbach's Alpha in the table are higher than 0.7, all items involved in this study are reliable to measure the variables.

Table 2. Reliability Analysis

\begin{tabular}{lcc}
\hline \multicolumn{1}{c}{ Variables } & Number of Items & Cronbach's Alpha \\
\hline Board Composition & 3 & 0.815 \\
Disclosure Practice & 2 & 0.827 \\
Stakeholder Management & 2 & 0.753 \\
Trust & 2 & 0.740 \\
All Variables & 9 & 0.866 \\
\hline
\end{tabular}

Source: Developed for the current research

Multiple regression is used to determine the importance of the independent variables in predicting the dependent variable (Sekaran \& Bougie, 2009) and could also identify the most influential factor that influence the dependent variable (Pallant, 2005). 
The standard multiple regression analysis produced results as shown in Table 3 . The analysis revealed the $\mathrm{R}$ squared of the model is 0.381 , while the adjusted $\mathrm{R}$ squared is 0.355 . This could be interpreted as the independent variables tested explain $38 \%$ of the variance in trust towards zakat institutions. The ANOVA on the other hand shows that the model is statistically significant (sig. $=0.000, \mathrm{p}<0.05$ ) with $\mathrm{F}$ value 14.384 . The probability value of 0.000 indicates that out of 1000 , there is no chance that the correlation coefficient is zero.

The standardised beta coefficients suggest the relative importance of each factor, with stakeholder management exerted the largest positive significant influence $(\beta=0.535, \mathrm{p}=0.000)$ followed by disclosure practice $(\beta=0.356, \mathrm{p}=0.002)$ and the last factor which is board capital recorded negative influence and not significant $(\beta=0.186, \mathrm{p}=0.572)$.

Table 3. Multiple Regression Analysis (Factors Influencing Trust)

\begin{tabular}{lccc}
\hline & $\begin{array}{c}\text { Standardized } \\
\text { Coefficients }\end{array}$ & $\begin{array}{c}\text { t- } \\
\text { value }\end{array}$ & Sig. \\
\hline & $\underline{\text { Beta }}$ & & \\
Board Capital & .186 & 0.567 & .572 \\
Disclosure Practices & .356 & 3.228 & .002 \\
Stakeholder Management & .535 & 5.271 & .000 \\
\hline R Square -0.381 & \multicolumn{2}{c}{ F-Value -14.384} \\
Adjusted R Square $=0.355$ & \multicolumn{2}{c}{ Sig. $=.000$} \\
\hline
\end{tabular}

Source: Developed for the current research

\section{Results and Discussion}

Based on the analysis above, it can be concluded that two out of three hypotheses are acceptable. Three factors have been proposed to influence trust in zakat institutions, which are board capital, disclosure practice and stakeholder management. A multiple regression analysis has been performed to find the factors that significantly influence trust among zakat payers towards zakat institutions. Result of the analysis reveals that only two factors have a significant positive relationship with trust which are disclosure practice and stakeholder management. For disclosure practices the result is in line with the previous research by where Mustafa et al. (2013) whereby they discovered that trust is created when a zakat institution is perceived to disclose broad based information to the public especially zakat payers.

Table 4: Hypothesis Testing

\begin{tabular}{llc}
\hline \multicolumn{1}{c}{ Hypotheses } & Status \\
\hline H1: & $\begin{array}{l}\text { Perception of the board capital of zakat institutions will have a positive } \\
\text { influence on trust towards zakat institutions among zakat payers. }\end{array}$ & Not Supported \\
\hline H2: & $\begin{array}{l}\text { Perception of the quality of the disclosure practices of zakat institutions } \\
\text { will have a positive influence on trust towards zakat institutions among }\end{array}$ & Supported \\
& \\
\hline zakat payers. & $\begin{array}{l}\text { Perception of the quality of stakeholder management practices of zakat } \\
\text { institutions will have a positive influence on trust towards zakat } \\
\text { institutions among zakat payers. }\end{array}$ & \\
\hline
\end{tabular}

Meanwhile, Mustafa et al. (2013) also found that the perception of stakeholders' management is operationalized as a series of activities that zakat payers expect zakat institutions to carry out in ensuring fairness to all stakeholders and guarantee their legitimacy. Among the item are included in stakeholder management is zakat institutions should systematically assess the satisfaction of zakat payer on regular basis. Zakat payers' trust can be developed according to the customer satisfaction index for zakat organizations developed by Said, et al (2012). The index 
comprises five items which are compliance to Islamic principles, reliability, tangibles, empathy and responsiveness. Table 4 provided the summary of the hypotheses.

\section{Conclusion}

In conclusion, it can be concluded that trust plays a vital factor for the Muslim business owner in paying zakat through official and proper zakat collection institution. In this regard, the zakat institution should make a proper step in order to increase the level of trust among the zakat payers as suggested in this study. This will minimize and avoid direct distribution of zakat payment by the Muslim business owner to the beneficiary. Zakat collection and distribution managed by the official zakat institution have been proved to be more effective and comprehensive benefits to the asnaf and general ummah will be achieved.

Based on the findings of this study, there are several implications and recommendation need to be considered in improving trust towards zakat institutions.

First, since stakeholder management has been proven to play the most significant role in influencing trust towards zakat institutions, it is important for zakat institutions to look into the underlying factors that could build and maintain their stakeholder. Looking into the context of this study, stakeholder management closely related to the satisfaction of zakat payers as the collection of zakat rely on them.

Second, the significant relationship between disclosure practice and trust indicated the importance of zakat institutions to be transparent. In order to gain high levels of trust and confidence of zakat payers in zakat institutions as well as to secure greater zakat collection amount by zakat institutions, this study has ascertained the antecedents of zakat payers' trust as means to improve the amount of zakat collection. Zakat institution may have to reconsider the level of public disclosure regarding management of zakat funds particularly its financial information. Perhaps such public awareness will result in greater familiarity with the practices of zakat institutions therefore, fostering greater participation and support. Thus, greater familiarity and high level of information disclosure to the public may improve positive reputation and acknowledge the zakat institutions' role and competence in managing zakat.

Furthermore, it is suggested that the government incorporated the zakat program in national economic program. As zakat can serve as an effective tool to eradicate poverty, the zakat institutions should be getting more attention from the government and be incorporated in national economic program. For example, the government may inject funding to the zakat institutions especially those that have shown good performance and having good financial soundness. Since the main objective of zakat is to alleviate poverty, the success of the zakat program would help the overall policy in reducing poverty rate.

\section{References}

Abojeib, M., \& Habib, F. (2019). Blockchain for Islamic social responsibility institutions. In FinTech as a Disruptive Technology for Financial Institutions (pp. 221-240). IGI Global. DOI: 10.4018/978-1-5225-7805-5.ch010

Baharum, M. A. (1989). Zakat ditinjau dari perspektff sosral Undang-Undang dan taksiran. Kuala Lumpur: Angkatan Belia lslam Malaysia

Berman, S. L., Wicks, A.C., Kotha, S. \& Jones, T.M (1999), Does stakeholder orientation matter? the relationship between stakeholder management models and the firm financial performance, The Academy of Management Journal, 42(5), 488-509. DOI: 10.2307/256972

Ghazali, M. Z., Saad, R., Jaffri \& Wahab, N.S.A. (2016). Proposing factors influencing trust towards zakat institutions amongst moslem business owners. In The European Proceedings of Social \& Behavioural Sciences - II International Scientific Symposium on Lifelong Wellbeing in the 


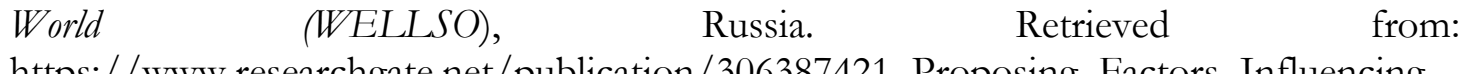
https://www.researchgate.net/publication/306387421 Proposing Factors Influencing Trust towards Zakat Institutions amongst Moslem Business Owners

Hasan, N.M.N., (1987). Zakat in Malaysia: present and future status. IIUM Journal of Economics and Management, IIUM Journal of Economis and Management, . 1(1), 47-75. Retrieved from: https://journals.iium.edu.my/enmjournal/index.php/enmj/article/view/4

Hillman, A. I., \& Dalziel, T. (2003). Boards of directors and firm-performance: integrating agency and resource dependence perspective. Academy of Management Review, 28(3), 383-396. Retrieved

from: https://www.jstor.org/stable/30040728?seq=1\#metadata_info_tab_contents

Krejcie, R. V. \& Morgan, D. W. (1970). Determining sample size for research activities. Educational and Psychological Measurement,30(3), 607-610. Retrieved from: https://home.kku.ac.th/sompong/guest_speaker/KrejcieandMorgan_article.pdf

Muhammad, F., Hussin, M. Y. M, Razak, A.A. \& Awang, S.A. (2015). Ketirisan bayaran zakat fitrah terhadap institusi formal di Malaysia. Jurnal Sains Humanika, 5(1) 27-32. DOI:10.11113/sh.v5n1.590

Mustafa, M.O.A., Mohamad, M.H.S \& Adnan, M. A. (2013). Antecedents of Zakat payers' trust in an emerging zakat sector: an exploratory study. Journal of Islamic Accounting and Business Research 4, 1: 4-25. DOI: 10.1108/17590811311314267

Obieoya, M.M., Mohamad, M.H, \& Adnan, M.A. (2011). Antecedents of zakat payers' trust: the case of Nigeria. International Journal of Economics, Management \& Accounting, 3(19), 133-164. Retrieved

from: https://journals.iium.edu.my/enmjournal/index.php/enmj/article/view/204

Patmawati, I. (20,08). Pembangunan Ekonomi Melalui Agihan Zakat: Tinjauan Empirikal". Shariah Journal 16(2), 223-244. Retrieved from: https://www.researchgate.net/publication/242206544_Pembangunan_Ekonomi_Melalui _Tagihan_Zakat_Tinjauan_Empirikal/citation/download

Pallant, J. (2005). SPSS survival guide. Crow's Nest, NSW: Allen \& Unwin.

Salleh, I \& Ahmad, S (2011). Indeks keyakinan terhadap lembaga zakat Selangor (LZS): Kajian kes kakitangan Universiti Kebangsaan Malaysia. Paper presented at Persidangan Kebangsaan Ekonomi Malaysia Ke VI (PERKEM VI), Malaysia. Retrieved from: http://www.ukm.my/fep/perkem/pdf/perkemVI/PERKEM2011-1-1B3.pdf

Said, J., Ghani, E.K., Hayati, N. \& Yusof, S. N. S. (2012). Composite performance measurement for zakat organisations. British Journal of Economics, Finance and Management Sciences, 4(2), 50 59. Retrieved from: https://www.semanticscholar.org/paper/Composite-PerformanceMeasurement-for-Zakat-Said-Ghani/0ca66d393aa0722e08594668caf7e6997aaadc28

Sekaran, U., \& Bougie, R. (2009). Research methods for business: a skill building approach. 5th Edition. West Sussex: John Wiley and Sons.

Sargeant A, \& Lee S. (2004). Donor trust and relationship commitment in the UK charity sector: the impact on behavior. Nonprofit and Voluntary Sector Quarterly, 33(2), 185 - 202. DOI: $10.1177 / 0899764004263321$

Wahab, A. A \& Borhan, J.T. (2014). Faktor penentu pembayaran zakat oleh entiti perniagaan di Malaysia: satu tinjauan teori. Jurnal Syariah, 22, 3: 295-322. Retrieved from: http://mjlis.um.edu.my/index.php/JS/article/view/7860 
Wahib, H, Ahmad, S \& Kader, R. A. (2009). Pengagihan zakat oleh institutusi zakat di Malaysia: mengapa masyarakat Islam tidak berpuas hati. Jurnal Syariah, 17(1), 89-112. Retrieved from:

http://www.ukm.my/hairun/kertas\%20kerja/IV C 2 hairunizam agihan zakat.pdf

Wahib, H., Ahmad., \& Adnan, M. (2006). Penswastaan institusi zakat dan kesannya terhadap pembayaran secara formal di Malaysia. International Journal of Management Studies 13, 2: 175196. Retrieved from: http://repo.uum.edu.my/1081/

Zainal, H., Bakar, A. A., \& Saad, R. A. J. (2016). Reputation, satisfaction of zakat distribution, and service quality as determinant of stakeholder trust in zakat institutions. International Journal of Economics and Financial Issues, 6(75), 72-76. Retrieved from: https://www.econjournals.com/index.php/ijefi/article/view/3581

Zakaria, S. (2009). Public trust of zakat management in the office of religious affairs, Cipocok Jaya, Serang, Banten, Indonesia. Journal of Management and Sustainability, 5(3), 155-165. DOI:10.5539/jms.v5n3p155 